Imperial Citizens 



\section{Imperial Citizens}

Koreans and Race from Seoul to $L A$

Nadia Y. Kim 
Stanford University Press

Stanford, California

(C)2008 by the Board of Trustees of the Leland Stanford Junior University. All rights reserved.

No part of this book may be reproduced or transmitted in any form or by any means, electronic or mechanical, including photocopying and recording, or in any information storage or retrieval system without the prior written permission of Stanford University Press.

Printed in the United States of America on acid-free, archival-quality paper

Library of Congress Cataloging-in-Publication Data

Kim, Nadia Y.

Imperial citizens : Koreans and race from Seoul to LA / Nadia Y. Kim.

p. $\mathrm{cm}$.

Includes bibliographical references and index.

ISBN 978-0-8047-5886-4 (cloth : alk. paper)—ISBN 978-0-8047-5887-1 (pbk. : alk. paper)

1. Korean Americans-Race identity-Case studies. 2. Korean Americans-Social conditions-Case studies. 3. Immigrants-United States-Social conditions-Case studies. 4. Racism-United States-Case studies. 5. Imperialism-Social aspects-United StatesCase studies. 6. United States-Race relations-Case studies. 7. Korean AmericansCalifornia-Los Angeles-Social conditions. 8. Koreans-Korea (South)-Seoul-Social conditions. 9. Los Angeles (Calif.) —Race relations. 10. Seoul (Korea)—Race relations.

I. Title.

E184.K6K486 2008

305.895'707979494-dc22 2007049983

Typeset by Westchester Book Group in 10/14 Minion 
To my dad,

for a love that outlives your Time. Your dreams wake me up every day.

To Ty,

for selflessly guiding us here when the world had other plans. 

There is a hole to escape through even when the sky collapses on us.

—Korean proverb 
